\title{
Паховий фасціїт “під маскою” епідидиміту
}

\begin{abstract}
У роботі розглянуто актуальне питання гнійної хірургії - лікування хворих на некротизуючий фасціїт, захворювання, яке маніфестується сепсисом та ендотоксикозом. Смертність за умов лікування сягає 30-80 \%, а в нелікованих - 100 \%. Проблема є актуальною через кількість таких хворих за останні 10 років зросла в 2 - 6 разів.

Проаналізовано випадок лікування хворого на некротизуючий фасціїт із його паховою локалізацією.

У доступній літературі є згадки про аналіз хворих на некротизуючий фасціїт із мультилокулярною локалізацією, але відсутні відомості про випадок, ідентичний нашому. В роботі описано первинне операційне втручання з приводу “так званого” епідидиміту. Окрім того, розглянуто симптоми, які допомогли запідозрити у хворого наявний некротизуючий фасціїт. Наведено дані стосовно патогістологічного аналізу операційного матеріалу й описано подальшу хірургічну тактику. Даний випадок є інформативним, оскільки свідчить про можливий атиповий перебіг некротизуючого фасціїту, зокрема в паховій ділянці. Окрім того, у хворого первинний некроз маніфестно локалізувався в жировій тканині і поверхневій фасції тіла поблизу зовнішнього отвору пахового каналу.
\end{abstract}

Ключові слова: некротизуючий фасціїт; гострий епідидиміт; некроз жирової тканини; рідкий ексудат чорного кольору; марлеві тампони за типом “частоколу”.

Проблема хірургічних інфекцій за актуальністю у всі часи відрізнялася особливою значущістю через полівалентність та тяжкість клінічних проявів, нестандартність лікувальних технологій і високу летальність. Особливо це стосується генералізованих форм інфекції з розвитком сепсису і поліорганної недостатності [2].

Незатребуваним виявився вид моделі тяжкого сепсису - некротизуючий фасціїт, рідкісна і надто небезпечна для життя хвороба. Летальність при цьому завхорюванні у лікованих хворих сягає 50$70 \%$, а без операційного лікування $100 \%$ [3, 5].

Некротизуючий фасціїт - різновид тяжкої групи хірургічних інфекцій м'яких тканин, спричинених Staphilococcus pyogenes чи змішаною флорою.

Це захворювання було відоме ще за часів Гіппократа. Вперше клінічну картину некротизуючого фасціїту описав американський військовий лікар Joseph Jones в 1871 році. Це захворювання називають шпитальна гангрена. Дефініцію “некротизуючий фасціїт” увів B. Willson в 1952 р. на основі виявлення у таких хворих клінічної картини ендотоксикозу й основної патогномонічної ознаки цієї хвороби - некрозу поверхневої фасції тіла $[1,6]$.

Частота цього захворювання, за даними R. Kaul (1997), становить 0,4 на 100000 населення. Щорічно в США реєструють 1500 випадків (F. Stone et al., 1998), у Великій Британії - до 500 (S. Hasman, 2005) [7].

Число таких хворих прогресивно зростає, особливо в країнах, які розвиваються, та на Африканському континенті. За останні десятиліття відзначається зростання кількості хворих на урогенітальний різновид некротизуючого фасціїту (гангрена Фурньє) в 2,2-6,4 раза [1].

Слід зазначити, що захворювання не має сезонності. Збудником цього захворювання $\epsilon$ мікстна аеробно-анаеробна інфекція з участю неклостридіальних анаеробів [2].

У літературі описано випадки некротизуючого фасціїту з мультифокальними ураженнями зон тіла, анатомічно не пов’язаних між собою [4].

У нашій клінічній практиці трапився випадок 3 некротизуючим фасціїтом пахової ділянки, що клінічно проявлявся ознаками гострого епідидиміту.

Мета роботи: на власному клінічному досвіді показати особливості діагностики, перебігу та хірургічного лікування пахового некротичного фасціїту “під маскою” гострого епідидиміту.

Хворий А., 43 роки, історія хвороби № 247/ 2021 госпіталізований зі скаргами на збільшення в розмірах правої половини калитки, її болючість та щільність. Окрім того, спостерігали субфебрильну температуру тіла. Захворів гостро за добу до госпіталізації серед повного здоров'я, коли з'явилися вищезгадані скарги. При УЗД яєчка інтактні, помірно потовщений придаток правого яєчка. У верхньому куті правої половини калитки рідинний утвір об'ємом понад 7 см $^{3}$ із множинними грубими перегородками, сім’яний канатик потовщений до 13 мм, в поперечнику гідрофільний, з нечіткими структурами.

Загальний аналіз крові на момент госпіталізації: лейкоцитоз до 14,7 · $10^{9}$, формула крові: п - 4, с - 83, лімфоцити -7 , моноцити - 6. Сечовина 
крові - 10,4 ммоль/л, креатинін 188 мкмоль/л, білірубін крові - 22,8 ммоль/л, АлАТ - 12 од., АсАТ - 31 од. Консервативне лікування впродовж 2 діб із застосуванням антибактеріальної і детоксикаційної терапії не дали позитивного результату.

Уражена права половина калитки збільшилась в розмірах. Хворого проконсультував хірург. Окрім епідидиміту, діагностовано і фунікуліт.

За результатами консультації хірурга та перебігу процесу хворому було запропоновано операційне лікування - ревізія правої половини калитки, далі за показаннями. В ході операції в правій половині калитки підшкірно виявили до 75 мл жовтого прозорого ексудату. Патологічних змін яєчка та його придатка на стороні ураження калитки не виявлено. Внаслідок потовщенням сім'яного канатика виконано його декомпресію шляхом фасціотомії власної фасції сім'яного канатика. Оскільки потовщення сім'яного канатика простягалось аж до його виходу із пахового каналу, було виконано додатковий розтин шкіри в проекції зовнішнього отвору пахвового каналу на шкіру. При фасціотомії виділяли помірну кількість жовтого прозорого ексудату при ретельній ревізії пахової ділянки поблизу зовнішнього отвору пахвового каналу виявлено зону некрозу підшкірної клітковини розміром 3.4 см, яку максимально можливо забрано, тканину направлено на гістологічне дослідження на кафедру патологічної анатомії Львівського НМУ імені Данила Галицького. Гістологічне заключення № 569 / 2021 гострий некротичний запальний процес жирової тканини нез'ясованого генезу.

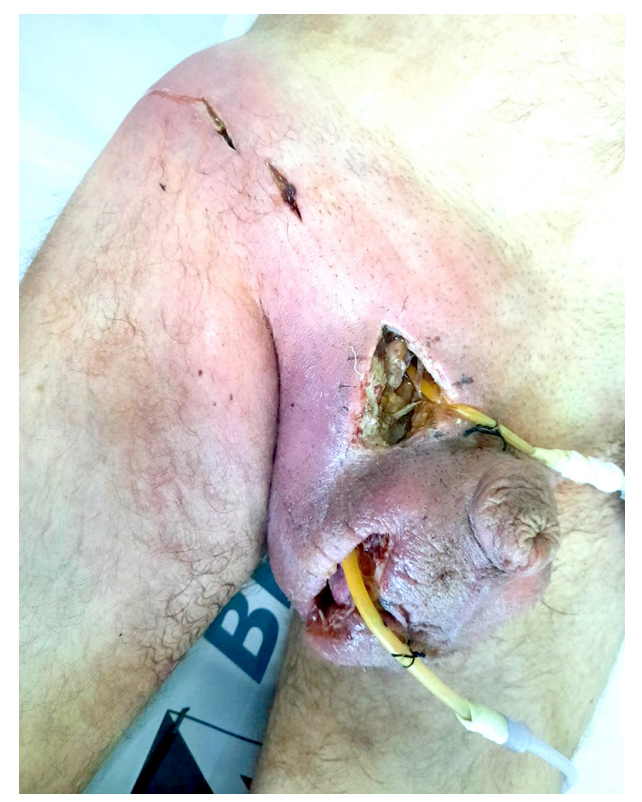

Рис. 1. Вигляд ран опісля зняття швів на третю добу після первинного втручання.
У ході операції обидва як паховий розтин, так і розтин калитки дреновано трубчастими дренажами значного діаметра. На рани накладено ситуаційні навідні шви.

3 обох дренажів впродовж перших двох діб виділяли сумарно до 0,5 л рідкого ексудату чорного кольору зі смердючим запахом за добу.

Наявність ексудату чорного кольору зі специфічним запахом за відсутності на той момент патогістологічного заключення дало змогу розцінити захворювання у хворого і діагностувати некротизуючий фасціїт пахової ділянки.

Проведено бактеріологічне дослідження ексудату із ран, виявлено St. aureus $10^{5} \mathrm{KУO} \mathrm{/} \mathrm{мл.}$

3 огляду на наявність некротизуючого фасціїту шви 3 обох ран зняли на третій день після первинного операційного втручання (рис. 1). Рани дреновано та виповнено марлевими випускниками, просякнутими 3 \% розчином перикису водню, розміщеними в рані за типом частоколу (рис. 2). У подальшому впродовж 3-х тижнів з інтервалом у 3 дні виконували етапні некректомії аж до отримання в рані достиглих грануляцій. В ході лікування було відзначено наявність “септичних метастазів” у правій клубовій ділянці, що змусило виконати в цій ділянці додаткові інцизіо і дренування (рис. 3).

Хворий отримував впродовж двох тижнів інтенсивну інфузійну терапію об'ємом до 2,5 л на добу, антикоагулянтну терапію низькомолекулярними гепаринаими, антибактеріальну терапію трьома антибактеріальними препаратами впродовж 3 тижнів та імуномодулюючу терапію.

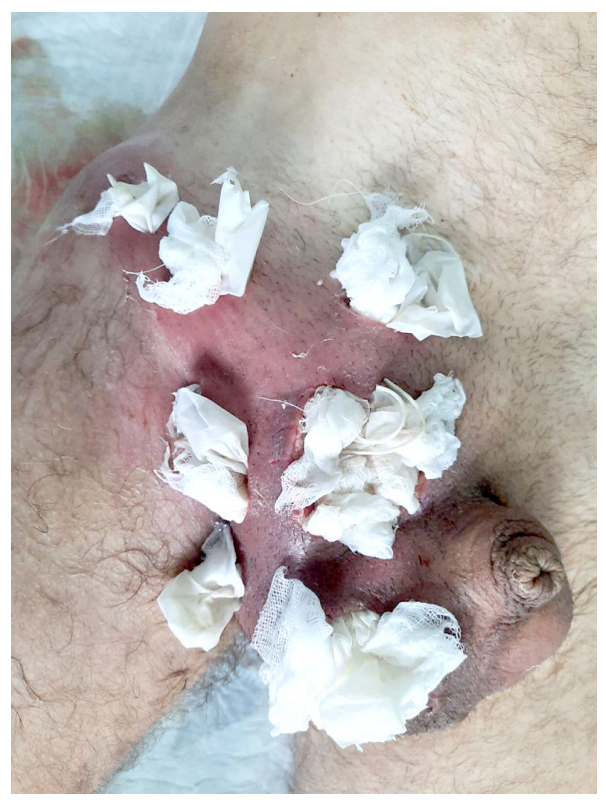

Рис. 2. Дренування ран при некротизуючому фасціїті пахової локалізаї. 


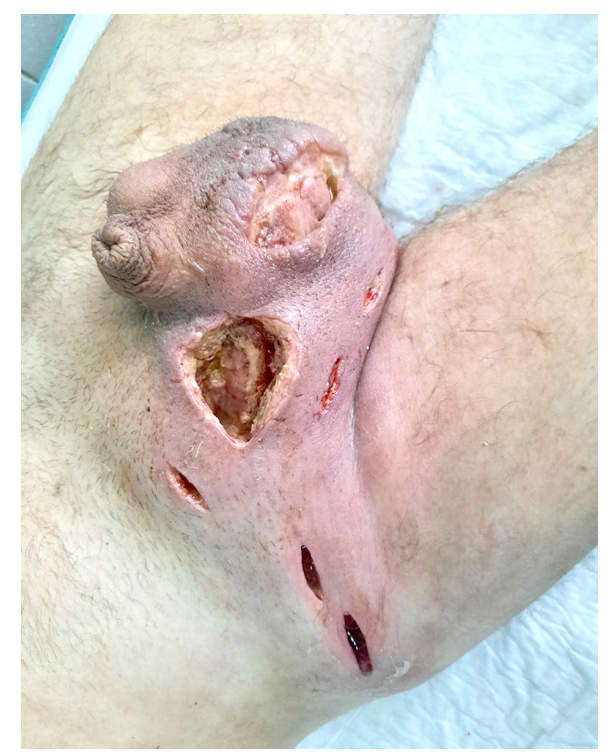

Рис. 3. Вигляд ран на момент формування “септичних метастазів” у правій клубовій зоні.

Після 4 тижнів стаціонарного лікування хворого виписали для лікування амбулаторно в хірурга за місцем проживання. На момент виписування рани виповнені достиглими грануляціями. Від повторного операційного втручання - пластика калитки та накладання вторинних швів на рани в паху і клубової ділянки хворий категорично відмовився. Повторно оглянутий через 2 місяці після виписування. Усі рани загоєнні первинним чи вторинним натягом (рис. 4).

\section{СПИСОК ЛІТЕРАТУРИ}

1. Алиев С. А. Болезнь Фурнье в свете современных представлений / С. А. Алиев, Е. С. Алиев, В. М. Зейналов // Хирургия. - № 4. - С. 34-39.

2. Тимербулатов В. М. Гангрена Фурнье / В. М. Тимербулатов, А. Г. Хасанов, М. В. Тимербулатов // Хирургия. - 2009. - № 3. - C. 26-28.

3. Гринев М. В. Некротизируюший фасциит / М. В. Гринев, Кир. М. Гринев. - СПб. : Гиппократ, 2008. - 120 с.

4. Стояновський I. В. Мультифокальний некротизуючий фасціїт: опис випадку та аналіз літератури / I. В. Стояновський // Шпитальна хірургія. Журнал імені Л. Я. Ковальчука. - 2013. - № 3. - С. 103-106.

\section{REFERENCES}

1. Aliev, S.A., Aliev, E.S., \& Zeynalov, V.M. (2014). Bolezn Fournie v svete sovremennyh predstavleniy [Fournier's disease in the light of modern ideas]. Hirurgiya - Surgery, 4, 34-39 [in Russian].

2. Timerbulatov, V.M., Khasanov, A.G., \& Timerbulatov, M.V. (2009). Fournie gangrena [Fournier's gangrene]. Hirurgiya - Sur-

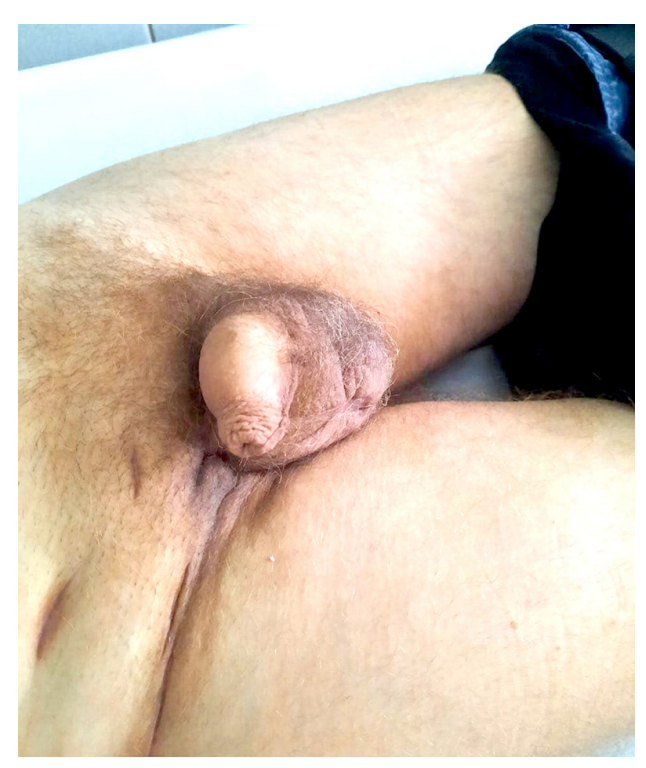

Рис. 4. Вигляд хворого опісля самостійного загоєння операційних ран.

Цей випадок є інформативний в тому плані, що паховий фасціїт може маскуватися ознаками гострого епідидиміту і фунікуліту. Необхідно зазначити, що при ретельному УЗД не виявлено ознак анаеробної інфекції - наявність підшкірно в паху чи в калитці газа. Хоча характер ексудату з рани і перебіг процесу свідчили про участь у даному процесі анаеробної інфекції. Спостереження ще раз показує на скільки складне є лікування, а особливо діагностика некротизуючого фасціїту.

5. Гангрена Фурньє як урогенітальна форма некротизуючого фасціїту - модель критичного стану організму в хірургії / О. Б. Прийма, І. В. Федорович, В. В. Корінь, Г. Я. Оленич // Шпитальна хірургія. Журнал імені Л. Я. Ковальчука. - 2017. - № 1. - C. 81-84.

6. Fournier's gangrene: etiology and outcome analysis of 41 patients / S. Altarac, D. Katusin, S. Crnica [et al.] // Urol. Int. 2012. - Vol. 88, No. 3. - P. 289-293.

7. Fournier's gangrene. A retrospective study of 41 cases / J. T. Barreda, M. M. Scheiding, C. S. Fernandez [et al.] // Cir. Esp. - 2010. - Vol. 87, No. 4. - P. 218-223. 


\section{ПОВІДОМЛЕННЯ}

rurhiia. Zhurnal imeni L. Ya. Kovalchuka - Hospital Surgery. Journal named after L.Ya. Kovalchuk. Retrieved from: https://doi. org/10.11603/1681-2778.2013.3.1814 [in Ukrainian].

5. Pryima, O.B., Fedorovych, I.V., KORIN, V.V., Olenych, G.Ya. (2017). Gangrena Furnie yak urohenitalna forma nekrotyzuiuchoho fastsyitu - model krytychnoho stanu orhanizmu v khirurhii [Fournier's gangrene as a urogenital form of necrotizing fasciitis is a model of a critical condition of the body in surgery]. Hospitalna
Khirurhiia. Zhurnal imeni L. Ya. Kovalchuka - Hospital Surgery. Journal named after L.Ya. Kovalchuk, 1, 81-84 [in Ukrainian]. 6. Altarac, S., Katusin, D., \& Crnica, S. (2012). Fournier's gangrene: etiology and outcome analysis of 41 patients. Urol. Int., 88 (3), 289-293.

7. Barreda, J.T., Scheiding, M.M., \& Fernandez, C.S. (2010). Fournier's gangrene. A retrospective study of 41 cases. Cir. Esp., 87 (4), 218-223.

\section{O. B. PRYIMA}

Truskavets Municipal Hospital

\section{INGUINAL FASCIITIS “UNDER THE MASK” OF EPIDIDYMITIS}

The topical issue of purulent surgery - treatment of patients with necrotizing fasciitis is considered in the work. This disease is manifested by sepsis and endotoxicosis. Mortality under treatment reaches 30-80 \%. Mortality in untreated patients is $100 \%$. The problem is relevant because the number of such patients has increased 2-6 times over the past 10 years.

In this work the case of treatment of a patient with necrotizing fasciitis with its inguinal localization is analyzed.

In the available literature, we found an analysis of patients with necrotizing fasciitis with multilocular localization. But we did not encounter a situation identical to our case. The paper describes the primary surgery for "so-called" epididymitis. In addition, the symptoms that helped to suspect the presence of necrotizing fasciitis were indicated. Data on the histopathological analysis of the operative material are given and further surgical tactics are described.

This case is instructive in that it indicates a possible atypical course of necrotizing fasciitis, in particular in the groin area. In addition, in this patient, the primary necrosis was manifestly localized in adipose tissue and superficial fascia of the body near the outer opening of the axillary canal.

Key words: necrotizing fasciitis; acute epididymitis; adipose tissue necrosis; black liquid exudate; gauze tampons of the "palisade” type. 